\title{
INVESTIGATION OF PbO-TiO $2-\mathrm{P}_{2} \mathrm{O}_{5}$ GLASS FORMING REGION
}

\author{
HICHAM MOHMOH $^{1}$, KARIM TOUILI $^{1}$, MALIKA OUCHETTO $^{1}$ \\ AND BRAHIM ELOUADI ${ }^{* 2}$
}

1.- Laboratoire de Chimie du Solide Appliquée, (Laboratoire Associé Francophone LAF 501), Faculté des Sciences, Charia Ibn Batota, B.P 1014, Rabat, Morocco.

2.- L E A C I M, Université de La Rochelle, Département de Chimie, avenue Marillac, 17042 La Rochelle Cédex 01, France.

\begin{abstract}
The glass forming range of $\mathrm{PbO}-\mathrm{TiO}_{2}-\mathrm{P}_{2} \mathrm{O}_{5}$ system has been determined at $1000^{\circ} \mathrm{C}$. The bulk density was measured and the 'molar volume have been calculated for both binary and ternary phosphate glasses. Infrared spectroscopy has been used in $1500-400 \mathrm{~cm}^{-1}$ region to assess structural changes taking place along the glass region of the lines $x$ PbO- $(1-\mathrm{x}) \mathrm{P}_{2} \mathrm{O}_{5}$ and $\mathrm{xPbO}-0.01 \mathrm{TiO}_{2}-(0.99-\mathrm{x}) \mathrm{P}_{2} \mathrm{O}_{5}$ by gradual passage from $\mathrm{v}-\mathrm{P}_{2} \mathrm{O}_{5}$ network to the end point of the glass forming domain $(x=0,64)$. The infrared deconvolution analysis has revealed that the stretching vibration of phosphoryl group persists in all investigated glasses up to $x=0,64$. This feature has been ascribed to the fact that the $\mathrm{P}=\mathrm{O}$ is not completely ruptured regardless the breakdown of the covalent phosphate glass network.
\end{abstract}

\section{$\underline{\text { INTRODUCTION }}$}

The phosphorus pentoxide $\mathrm{P}_{2} \mathrm{O}_{5}$ was postulated as glass forming oxide along with de $\mathrm{SiO}_{2}$ and $\mathrm{B}_{2} \mathrm{O}_{3}{ }^{1}$. The later two glass-forming oxides have been extensively used as glass-ceramics containing ferroelectric phases such as $\mathrm{PbTiO}_{3}, \mathrm{BaTiO}_{3}$ and $\mathrm{SrTiO}_{3}{ }^{2-4}$. However, the hygroscopic and volatile nature of $\mathrm{P}_{2} \mathrm{O}_{5}$ have hampered the use of its glassy state in this field. Moreover, because of the extreme difference in melting point between $\mathrm{TiO}_{2}$ and $\mathrm{P}_{2} \mathrm{O}_{5}{ }^{5}$, the preparation of homogenous glasses in this system is a difficult task. For these reasons, there have been very few detailed studies on the $\mathrm{TiO}_{2}$ $\mathrm{P}_{2} \mathrm{O}_{5}$ glasses ${ }^{6}$. Conversely, the bivalent phosphate glasses have received more attention, inasmuch as they are among the easiest glasses to prepare ${ }^{7-11}$.

The present work is part of our investigations devoted to the identification, structural and dielectric properties of both glass and vitro-ceramic domains within the ternary systems $\mathrm{B}^{\mathrm{II}} \mathrm{O}-\mathrm{TiO}_{2}-\mathrm{P}_{2} \mathrm{O}_{5}\left(\mathrm{~B}^{\mathrm{II}}=\mathrm{Mg}, \mathrm{Ca}, \mathrm{Sr}, \mathrm{Ba}, \mathrm{Pb}\right)^{12}$. The puropse of the present article is to report on the glasses isolated at $1000^{\circ} \mathrm{C}$, inside the ternary diagram $\mathrm{PbO}-\mathrm{TiO}_{2}-\mathrm{P}_{2} \mathrm{O}_{5}$. The relationship between their composition, density, molar volume and the evolution of their vibrational spectra will also be discussed.

\footnotetext{
* Author for correspondance
} 


\section{EXPERIMENTAL PROCEDURES}

Batches for glass melting were prepared by mixing appropriate amounts of metal oxides $\left(\mathrm{PbO}, \mathrm{TiO}_{2}\right)$ and $\mathrm{NH}_{4} \mathrm{H}_{2} \mathrm{PO}_{4}$. The glasses were melted in alumina crucibles at $950-1000^{\circ} \mathrm{C}$ (the temperature being kept constant for $30 \mathrm{~min}$ ), poured into preheated stainless steel plate to $350-400^{\circ} \mathrm{C}$, then allowed to cool normally to room temperature.

The glassy state was substantiated by the absence of the peaks in X-ray diffraction pattern. The mass densities were measured by the archimedes method using the diethylphtalate as an immersion fluid. From the density data, oxygen molar volume $\mathrm{V}(\mathrm{O})$ of each sample were calculated according to eq. $1^{13}$ :

$$
\mathrm{V}(\mathrm{O})_{\mathrm{i}}=\frac{\sum_{\mathrm{i}} \mathrm{M}_{\mathrm{i}} \mathrm{x}_{\mathrm{i}}}{\rho \sum_{\mathrm{i}} \mathrm{n}_{\mathrm{i}} \mathrm{x}_{\mathrm{i}}}
$$

where $\rho, M_{i}, x_{i}, n_{i}$ stand for measured bulk density of the glass, atomic weight, molar fraction and the number of oxygen atom, respectively. Fourier transformed infrared FTIR spectra were recorded with FTIR spectrophotometer PERKIN ELMER 1600 within $250-1500 \mathrm{~cm}^{-1}$ region, using $\mathrm{KBr}$ pellet technique.

\section{$\underline{\text { RESULTS }}$}

\section{- Glass forming region}

In the present study, neither $\mathrm{PbO}-\mathrm{TiO}_{2}$, nor $\mathrm{TiO}_{2}-\mathrm{P}_{2} \mathrm{O}_{5}$ system have yield glasses under the above described conditions. In the first diagram it is quite obvious. However, in the second one, it seams surprising as $\mathrm{P}_{2} \mathrm{O}_{5}$ is one of the four claimed glass forming oxides ${ }^{1}$, this discrepancy may be accounted for the great difference between the $\mathrm{P}_{2} \mathrm{O}_{5}$ and $\mathrm{TiO}_{2}$ melting points. The glass forming range was found to be extended up to $\mathrm{x}=0.64, \mathrm{x}$ denotes the molar fraction of $\mathrm{PbO}$. Figure 1 represents the glass forming range delimited in $\mathrm{P}_{2} \mathrm{O}_{5}-\mathrm{TiO}_{2}-\mathrm{PbO}$ system.

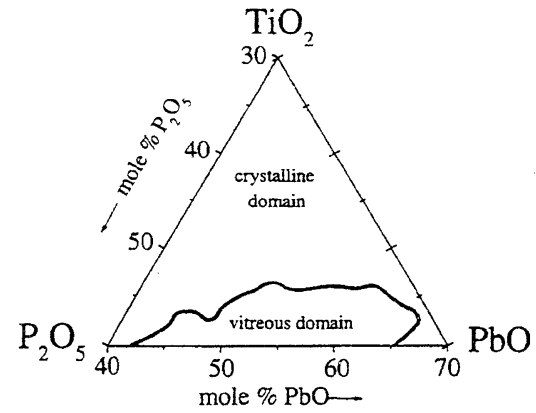

FIGURE 1 : Glass forming region in the $\mathrm{PbO}-\mathrm{TiO}_{2}-\mathrm{P}_{2} \mathrm{O}_{5}$ system at $1000^{\circ} \mathrm{C}$

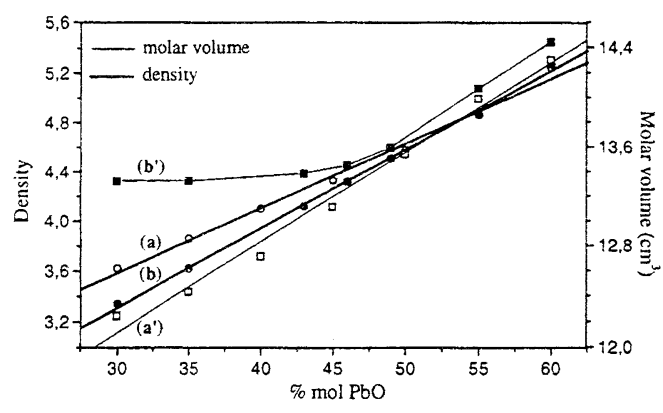

FIGURE 2 : Bulk density and molar volume of $(1-\mathrm{x}) \mathrm{P}_{2} \mathrm{O}_{5}-\mathrm{xPbO}\left(\mathrm{a}, \mathrm{a}^{\prime}\right)$ and $(0.99-\mathrm{x}) \mathrm{P}_{2} \mathrm{O}_{5}-0.01 \mathrm{TiO}_{2}-\mathrm{xPbO}\left(\mathrm{b}, \mathrm{b}^{\prime}\right)$ glass versus $\mathrm{PbO}$ contents 


\section{- bulk density and molar volume}

Figure 2 shows a linear increase in bulk density with the $\mathrm{PbO}$ content of both binary and ternary phosphate glasses. However, their corresponding calculated molar volume for one atom of oxygen of ternary phosphate glasses exhibits a different behaviour. It can be seen that the addition of 1 mole $\%$ of $\mathrm{TiO}_{2}$ (Fig. 2) to lead phosphate glasses with $\mathrm{x}=0.3$ yields a molar volume of $13.25 \mathrm{~cm}^{3}$, instead of 12.24 $\mathrm{cm}^{3}$ calculated for titanium free lead phosphate glass. Therefore, within the composition range $0.3 \leq \mathrm{x} \leq 0.5, \mathrm{~V}(\mathrm{O})$ remains constant regardless the $\mathrm{PbO}$ content. Thereafter, it augments with further addition of $\mathrm{PbO}$. These results suggest that firstly, the atomic weight of lead is the bulk density controlling factor and secondly, the $\mathrm{v}-\mathrm{P}_{2} \mathrm{O}_{5}$ structure is built with excess of structural volume with regard to its crytalline varieties. The calculated molar volumes from density data found in the literature for $\mathrm{v}^{-} \mathrm{P}_{2} \mathrm{O}_{5}$ and its

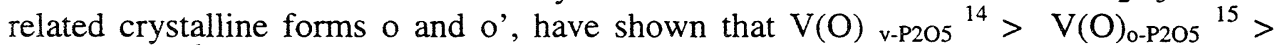
$\mathrm{V}(\mathrm{O})_{0^{\prime}-\mathrm{P} 205}{ }^{16}$. This excess could not assist the $\mathrm{Pb}^{2+}$ and $\mathrm{Ti}^{4+}$ incorporations, because their size are larger than the voids available within the glass network. Furthermore, in principle, the variation of physical properties, such as density and molar volume of a glass, seems to be closely related to its structural variation as discussed below.

\section{- Infrared spectra}

The vibrational spectroscopy has been used in the $400-1500 \mathrm{~cm}^{-1}$ region to identify the anionic species present in both series of glasses $x$ PbO- $(1-x) \mathrm{P}_{2} \mathrm{O}_{5}$ and $x \mathrm{PbO}-0.01 \mathrm{TiO}_{2}-(0.99-\mathrm{x}) \mathrm{P}_{2} \mathrm{O}_{5}$. Typical examples of spectra of the first series are presented in figure 3. The infrared spectrum of vitreous $\mathrm{P}_{2} \mathrm{O}_{5}$ is taken as a starting point and that of $x=0.64$ as end point of this series. This representation ought to facilitate the comparisons related to noticeable changes taking place in the lead phosphate glass structures. Before investigating the evolution of infrared spectra of this series, a careful re-examination of the reflectance calculated infrared absorption spectrum of vitreous $\mathrm{P}_{2} \mathrm{O}_{5}{ }^{17}$ was felt necessary. Unfortunately, in this case the band emerging from the region $1250-1150 \mathrm{~cm}^{-1}$ is found rather too intense. This band is likely resulting from the effect of humidity (due to the synthesis procedure ${ }^{17}$ ), giving rise $10-\mathrm{O}-\mathrm{H}$ group. Indeed, Meyer et al. ${ }^{18}$ have successfully recorded a better reflectance infrared spectrum of an almost anhydrous $\mathrm{P}_{2} \mathrm{O}_{5}$ glass with no such intense band. The band positions, in

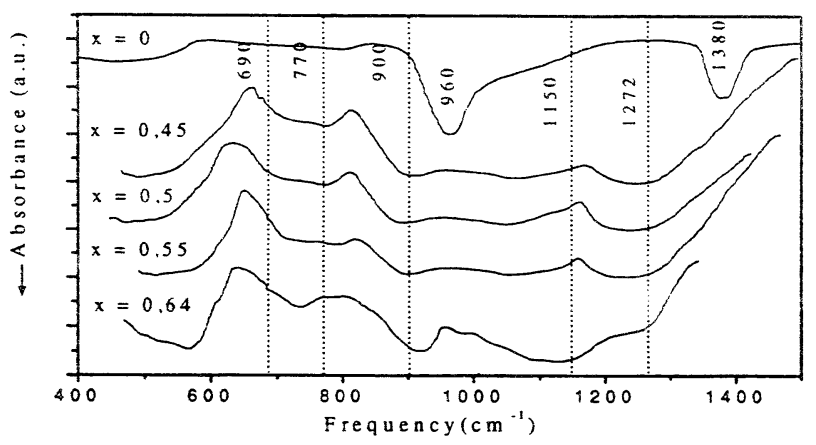

FIGURE 3 : Infrared absorption spectra of $(1-\mathrm{x}) \mathrm{P}_{2} \mathrm{O}_{5}-\mathrm{xPbO}$ glasses Compared with that of $\mathrm{v}-\mathrm{P}_{2} \mathrm{O}_{5}{ }^{18}$ 
both calculated absorbance from reflectance spectrum $^{18}$ and absorbance spectrum performed in $\mathrm{KBr}$ pellet ${ }^{19}$ of $\mathrm{P}_{2} \mathrm{O}_{5}$ glass, were found at about $1380,960,800-630 \mathrm{~cm}^{-1}$ and $500-300 \mathrm{~cm}^{-1}$ corresponding respectively to, the symmetric phosphoryl stretch $\mathrm{V}_{\mathrm{s}} \mathrm{P}=\mathrm{O}$, asymmetric stretching vibration of $\mathrm{P}-\mathrm{O}-\mathrm{P}$ bridges $\mathrm{V}_{\text {as }} \mathrm{P}-\mathrm{O}-\mathrm{P}$, symmetric stretching vibration of $\mathrm{P}-\mathrm{O}-\mathrm{P}$ and the phosphate skeleton deformation. These results are highly consistent with our formerly $\mathrm{v}-\mathrm{P}_{2} \mathrm{O}_{5}$ recorded Raman spectra ${ }^{20}$.

As the stretching modes of the phosphate tetrahedra labelled $Q^{1}, Q^{2}$ with one and two bridging oxygen respectively, all emerge $e^{21}$ in the region $1000-1150 \mathrm{~cm}^{-1}$. These bands exist in all the spectra except for $\mathrm{P}_{2} \mathrm{O}_{5}$, either as distinct or a shoulder-like feature at this region. There is another band complex appearing in $1200-1350 \mathrm{~cm}^{-1}$ region. This band complex consists of stretching vibration of phosphoryl group $v \mathrm{P}=\mathrm{O}$ and asymmetric stretching vibration of $\mathrm{Q}^{2}$ tetrahedra $\mathrm{V}_{\mathrm{a}} \mathrm{PO}_{2}$, both of which are not observed as separate and well defined bands, whose peak is located near $1272 \mathrm{~cm}^{-1}$ for ultraphosphates and its amplitude is smaller than that of $\approx 1150 \mathrm{~cm}^{-1}$ band, observed for $x=0.64$, which is associated with the symmetric stretching of $Q^{i}\left(v_{a s} P_{3}\right)$. The decrease of the maximum amplitude of the band at $1272 \mathrm{~cm}^{-1}$ is accompanied by a shift towards lower frequencies. There is also emergence and growth of bands in 960-1100 $\mathrm{cm}^{-1}$ region. This region is attributed to the stretching vibration of $\mathrm{Q}^{1}$ tetrahedra possessing three unshared oxygen corners. The frequency range assigned to the asymmetric stretching vibration of P-O-P ( $v_{\mathrm{a}}$ P-O-P) shows a large and diffuse band whose peak is located around $900 \mathrm{~cm}^{-1}$. Whereas, the one attributed to the symmetric band stretching vibration of P-O-P linkages, exhibits two peaks whose maximum amplitudes are observed at $\approx 770 \mathrm{~cm}^{-1}$ and $\approx 690 \mathrm{~cm}^{-1}$ which are presumably due to the presence of several type of bridges P-O-P units ${ }^{22}$. The first one can be attributed to $v s$ $\mathrm{P}-\mathrm{O}-\mathrm{P}$ of $\mathrm{Q}^{2}$ tetrahedra and the second band to $\mathrm{V}_{\mathrm{S}} \mathrm{P}-\mathrm{O}-\mathrm{P}$ of $\mathrm{Q}^{3}$ tetrahedra, because the relative intensity of the band at $770 \mathrm{~cm}^{-1}$ is constantly increasing to the detriment of that at $690 \mathrm{~cm}^{-1}$ as the $\mathrm{PbO}$ content increases. According to Bruni et al. ${ }^{23}$, such bridges should have a bent configuration. Because, in the case of linear configuration, $v_{s} \mathrm{P}-\mathrm{O}-\mathrm{P}$ is only Raman active. As matter of fact, in $\left[\mathrm{Pb}\left(\mathrm{PO}_{3}\right)_{2}\right]_{\mathrm{x}}$ crystallising in space group $\mathrm{P} 2{ }_{1} / \mathrm{C}$, all the P-O-P angles are lower than $180^{\circ}$ : i. e. 147,143 and $138^{\circ} 24$.

As the infrared band complexes are large and diffuse, it is difficult to have a deeper insight into a glass structure, thus deconvolution analysis was felt necessary. The patterns of deconvolution analysis of $\mathbb{R}$ active modes of $x P b O-(1-x) \mathrm{P}_{2} \mathrm{O}_{5}$ glasses (figure 4), turned out to be even more complicated than that seen from the raw IR spectra. A minimum of seven bands were found, thus showing that the spectra comprise no less than ten active vibrational modes in the $600-1350 \mathrm{~cm}^{-1}$ range. According to Meyer et al. ${ }^{22}$, the interpretation of infrared spectra of $\mathrm{P}_{2} \mathrm{O}_{5}$ complicated structures essentially based on the number of $\mathrm{PO}_{4}$ per unit cell as well as the type of their connection and symmetry. Each $\mathrm{PO}_{4}$ with tree shared oxygen $\mathrm{Q}^{3}$ correspond to one $v_{s} \mathrm{P}=\mathrm{O}$, one $v_{s} \mathrm{P}-\mathrm{O}-\mathrm{P}$ and two $v_{\mathrm{as}} \mathrm{P}-\mathrm{O}-\mathrm{P}$ of the three bridging groups, as the number of non equivalent tetrahedra in $\left(\mathrm{P}_{2} \mathrm{O}_{5}\right)_{\infty}$ are two, one should expect, more than one infrared active mode for each group. As matter of fact, the deconvolution analysis meet theoretical expectation in both cases : $\mathrm{v}_{-} \mathrm{P}_{2} \mathrm{O}_{5}$ and lead metaphosphate glasses. For $\mathrm{Pb}\left(\mathrm{PO}_{3}\right)_{2}$ four stretching vibrations of each of the four mode : $\mathrm{v}_{\mathrm{as}} \mathrm{PO}_{2}, \mathrm{v}_{\mathrm{s}} \mathrm{PO}_{2}, \mathrm{v}_{a s} \mathrm{P}-\mathrm{O}-\mathrm{P}$ and $v_{\mathrm{s}} \mathrm{P}-\mathrm{O}-\mathrm{P}$ are expected, because its crystalline structure consists of meandering chains of four $\mathrm{PO}_{4}$ tetrahedra ${ }^{24}$. It seems instructive to point out that the structure of lead metaphosphate glass cannot be described in term of $\mathrm{Q}^{2}$ only. As the band appearing 
at $\approx 1130-1050 \mathrm{~cm}^{-1}$ region is predominant in the infrared spectrum of the composition $0.36 \mathrm{P}_{2} \mathrm{O}_{5}-0.64 \mathrm{PbO}$. This band is ascribed to $\mathrm{V}_{\mathrm{as}} \mathrm{PO}_{3}$ or $\mathrm{V}_{\mathrm{as}} \mathrm{P}-\mathrm{O}^{-}\left(\mathrm{Q}^{1}\right)$. These results suggest that the chain length is shorter than that of the corresponding crystalline form.
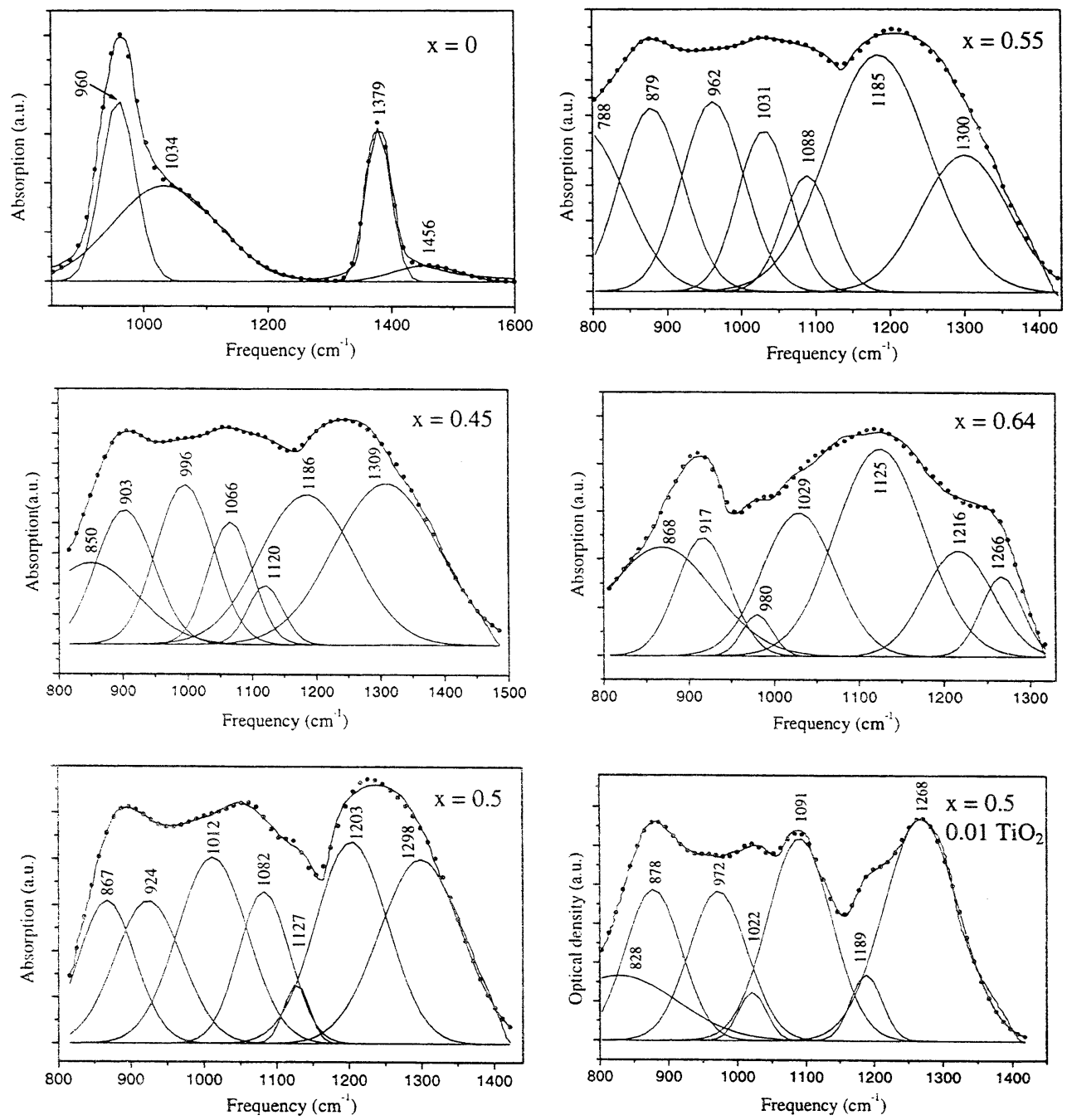

FIGURE 4: Deconvolution analysis of the infrared spectra of $(1-\mathrm{x}) \mathrm{P}_{2} \mathrm{O}_{5}-\mathrm{xPbO}$ and $0.49 \mathrm{PbO}-0.01 \mathrm{TiO}_{2}-0.5 \mathrm{P}_{2} \mathrm{O}_{5}$ glasses

- simulated band, $\sim$ experimental and ... simulated spectrum

A close examination of the whole serie of infrared deconvolution analysis spectra reveals that band ascribed to $\mathrm{vP}=\mathrm{O}$ persist in all the spectra even in those corresponding to $x>0.5$. However, its relative intensity as well as its wave number decrease when $\mathrm{PbO}$ content exceeds the metaphosphate compositions. This fact was explained on the basis of $\mathrm{Pb}^{2+}$ position between $\mathrm{P}-\mathrm{O}-\mathrm{P}$ layers. Thereby, they have direct 
interaction-between $\mathrm{Pb}^{2+}$ and phosphoryl group ${ }^{25.26}$. Therefore, the inclusion of $\mathrm{P}=\mathrm{O}$ bond into $\mathrm{Pb}^{2+}$ coordination sphere yields an elongation of $\mathrm{P}=\mathrm{O}$ bond and hence a drop in the wave number from $1300 \mathrm{~cm}^{-1}$ for metaphosphate to $1266 \mathrm{~cm}^{-1}$ for the oligophosphate composition of $\mathrm{x}=0.64 \mathrm{PbO}$. On the other hand, the continuous presence of $\mathrm{v}_{\mathrm{s}} \mathrm{P}=\mathrm{O}$ band from the $\mathrm{v}-\mathrm{P}_{2} \mathrm{O}_{5}$ to the highest limit of glass formation range indicates that no complete rupture of $\mathrm{P}=\mathrm{O}$ bond by $\mathrm{Pb}^{2+}$ occurs ${ }^{27}$. However, the emergence and growth of the bands located in $1130-1050 \mathrm{~cm}^{-1}$ region, associated with stretching vibration of the end group $\mathrm{PO}_{3}$ suggest a progressive break down of the covalent phosphate glass matrix as the $\mathrm{PbO}$ content increases.

It is worth noting that the Infrared spectra of titanium free-lead phosphates glasses are affected by the addition of $\mathrm{TiO}_{2}$ as illustrated by the clear differences between the spectra of the samples having the same $\mathrm{P}_{2} \mathrm{O}_{5}$ concentration $\mathrm{x}=0.5$. Specially in the frequency region associated with the general profile of the stretching vibrations of phosphate groups $\mathrm{PO}_{2}\left(\mathrm{Q}^{2}\right)$ and $\mathrm{PO}_{3}\left(\mathrm{Q}^{3}\right)$ (figure 4). The obtained data, from the $\mathbb{R}$ deconvolution analysis of both titanium free and $1 \% \mathrm{TiO}_{2}$ containing lead metaphosphate glass, on the inherent frequencies of the observed mode remain more or less unchanged. However, their intensity exhibits variable changes, mainly, in the case of those associated with symmetric and asymmetric stretching vibration of $\mathrm{PO}_{3}$ and $\mathrm{PO}_{2}$ groups. The intensity of the later modes increases at the expenses of the former ones. This is consistent with the fact that when $\mathrm{PbO}$ is replaced by $\mathrm{TiO}_{2}$, it tends to displace the glass forming region towards ultraphosphate domain. As a matter of fact, the latter region is more inclined to contain $\mathrm{PO}_{2}$ entities than the terminal groups $\mathrm{PO}_{3}$.

In addition, the molar volume increase observed in the case of titanium-lead metaphosphate glasses does not seem to be easily explained by simple mechanisms such as a differences of masses, field strength or polarizability between substituting $\mathrm{Ti}^{4+}$ and $\mathrm{Pb}^{2+}$ ions. Unlike the case of the $(45-\mathrm{x}) \mathrm{B}^{\mathrm{II}} \mathrm{O}-\mathrm{xNa}_{2} \mathrm{O}-2,5 \mathrm{Al}_{2} \mathrm{O}_{3}-52,5 \mathrm{P}_{2} \mathrm{O}_{5}\left(\mathrm{~B}^{\mathrm{II}}=\mathrm{Ca}, \mathrm{Sr}\right.$, $\mathrm{Ba}$ ) glasses, the decrease of molar volume deriving from the $\mathrm{B}^{2+}$ substituting for $\mathrm{Na}^{+}$, was explained on the basis of the field strength ${ }^{28}$. These changes could be accounted for the difference between the roles of $\mathrm{Ti}^{4+}$ and $\mathrm{Pb}^{2+}$ in the glass forming tendency. The $\mathrm{Ti}^{4+}$ and $\mathrm{Pb}^{2+}$ ions are presumably located in different sites. To determine the correlation between the molar volume and the structure, more experiments are needed.

\section{CONCLUSION}

The glass forming domain of the ternary system $\mathrm{PbO}-\mathrm{TiO}_{2}-\mathrm{P}_{2} \mathrm{O}_{5}$ has been determined at $1000^{\circ} \mathrm{C}$. The evolution of the bulk density with $\mathrm{PbO}$ content is found to be controlled by the atomic weight of lead.. The infrared spectroscopy has successfully allowed to identify the anionic species present in the glass structure. its deconvolution analysis has on one hand revealed the continuous existence of $\mathrm{P}=\mathrm{O}$ bond beyond the metaphosphate composition $(x=0,5)$ up to $x=0,64$ and in the other hand, the emergence and growth of the band ascribed to the end groups $\mathrm{PO}_{3}$. These results suggest a progressive breakdown of the covalent phosphate glass network without a complete rupture of $\mathrm{P}=\mathrm{O}$ bond by $\mathrm{Pb}^{2+}$ as the $\mathrm{PbO}$ content increases. The effect of titanium on lead phosphate glasses has been evidenced by the clear change in infrared spectra particularly in the region associated with the middle and the end group phosphate tetrahedra. 


\section{REFERENCES}

1 W. H. Zachariason, J. Am. Chem. Soc.; 54, 3841 (1932)

2 S. D. Stookey, U. S. Pat. 2,920,971 Ceramics Abstracts June. 142 (1960).

3 C. G. Bergeron, C. K. Russell, J. Am. Ceram. Soc., 48 (3), 115.(1965).

4 D. G. Grossman, PhD Thesis, University of Sheffield (1967).

5 S. M. Lang, C. L. Fillmore and L. H. Maxwell, J. Reseach Natl. Bur. Standars, $\underline{48}$ (4), 301 (1952).

6 R. K. Brow, D.R. Tallant, W. L. Warren, A. Mc Intyne and D. E. Day, Phys. Chem. Glasses, 38(6), 300 (1997).

7 G. Walter, U. Hoppe, T. Baade, R. Kranold, D. Stachel, J. Non-Cryst. Solids, 217, 299 (1997).

8 R. K. Brow, R. Tallant, S. T. Meyers, C. C. Phifer, J. Non-Cryst. Solids, 191, 45 (1995).

9 U. Hoppe, G. Walter, R. Kranold, D. Stachel, A. Barz, J. Non-Cryst. Solids, 192\&193, 28 (1995).

10 R. Kranold, G. Walter, U. Lembek, Th. Rieker, D. Stachel, J. Non-Cryst. Solids, 232\&234, 502 (1995).

11 H. S. Liu, T. S. Chin, S. W. Yung, Chem. Phys., 50, 1 (1997).

$12 \mathrm{~K}$. Touili, Thèse de Doctorat, Faculty of Sciences, Rabat, Morocco (1999).

13 H. Sholtze, Le Verre, Nature, Structure et Propriétés, Institut du Verre, Paris (1980)

14 K. Suzuya, D. L. Price, C. K. Loong and S. W. Martin, J. Non-Cryst. Solids, 232-234, 650 (1998).

15 El. H. Arbib, B. Elouadi, J. P. Chaminade and J. Darriet, J. Solid State Chem., 127, 350 (1996).

16 D. Stachel, I. Svoboda, H. Fuess, Act. Cryst., C51, 1049 (1995).

17 C. Garrigou-Lagrange, M. Ouchetto and B. Elouadi, Can. J. Chem., 63, 1436 (1985).

18 K. Meyer, A. Barz and D. Stachel, J. Non-Cryst. Solids, 191, 71 (1995).

19 J. J. Hudgens and S. W. Martin, J. Am. Ceram. Soc., 76 (7) 1691 (1993).

$20 \mathrm{M}$. Ouchetto, Thèse de Doctorat d'Etat es-science, Université Mohammed V, Rabat, Morocco (1993).

21 D. F. C. Coobridge "phosphorus and its compounds, vol.1, chemistry" in the infrared spectra of phosphorus compounds. Edited by J. R. Van Wazer. Interscience Publishers, New York, 235 (1958).

22 K. Meyer, H. Hobert, A. Barz and D. Stachel, Vib. Spectrosc., $\underline{6}, 323$ (1994).

23 S. Bruni, F. Cariati, A. Corrias, P. H. Gaskell, A. Lai, A. Musini and G. Piccaluga, J. phys. Chem., 99, 15229 (1995).

24 V. K. H. Jost, Acta Cryst., 17,1539 (1964).

25 Y. Dimitriev, V. Dimitrov, M. Annandov, D. Topalov, J. Non-Cryst. Solids, 57, 147 (1983).

26 S. Mandal and A. Ghosh, Phys. Rev. B Condens. Matter., 48, 9388 (1993).

27 C. Dayanand, G. Bhikshamaiah, V. Jaya Tyagaraju, M. Salagram and A. S. R. Krishna Murthy, J. Mater. Sci., 31, 1945 (1996).

28 J. O. Byun, B. H. Kim, K. S. Hong, H. J. Jump, S. W. Lee, A. A. Izyneev, J. Non-Cryst. Solids, 190,288 (1995). 